\title{
THE DISCUSSION OF QIRA'AT TURJUMAN AL-MUSTAFID EXEGESIS BOOK BY SHEIKH ABDUL RAUF SINGKEL
}

\author{
Khairunnas Jamal ${ }^{1}$ dan Wan Nasyaruddin Wan Abdullah ${ }^{2}$ \\ ${ }^{1}$ UIN Sultan Syarif Kasim Riau \\ ${ }^{2}$ UKM Malaysia \\ khairunnas.jamal@uin-suska.ac.id
}

\begin{abstract}
Muslims got mercy upon the provision of differences in reading al-Qur'an. The differences have made significant influence on the interpretation of the Holy Book. The commentators of al-Qur 'an adopted the qira'at differences as an integral part of their interpretation. For example, Ibn Jarir al-Tabari who wrote Tafsir al-Tabari and Abdul Rauf Singkel who wrote Tafsir Turjuman al-Mustafid. Abdul Rauf Singkel was a famous Qur'anic exegesis scholar in the Indonesia Archipelago whose work became the main reference of Muslims alongside the archipelago. In interpreting the verses of al-Qur'an, Abdul Rauf put qira'at distinction as one of his focuses of interpretation. In his work, Shaikh Abdul Rauf cited only three of the available seven qira'ats that he considered mutawatir and valid. Among those three qira'ats is qira'at Imam Nafi', qira'at Imam Abu Amr and qira'at Imam Hafash. This study has shown despite differences in the implication of the qira'ats, there also the differences in meaning and understanding. Shaikh Abdul Rauf merely provided information about the difference in readings rather than showing a difference of meaning contained in each of the differences.
\end{abstract}

Keywords: Qira'at, Turjuman al-Mustafid, Abdul Rauf Singkel, and Tafsir.

\begin{abstract}
Abstrak
Perbedaan bacaan yang terdapat dalam al-Qur'an merupakan sebuah rahmat bagi umat Islam. Perbedaan itu memberikan kemudahan bagi umat Islam untuk membaca al-Qur'an serta memberikan pengaruh yang signifikan terhadap penafsiran al-Qur'an. Para mufassir al-Qur'an selalu mengadopsi perbedaan qira'at tersebut sebagai bagian integral dari penafsiran mereka. Sebut saja Ibnu Jarir al Thabari yang menulis tafsir al-Thabari serta Abdul Rauf Singkel yang menulis tafsir Turjuman al-Mustafid. Abdul Rauf Singkel adalah seorang ulama nusantara yang telah berhasil menulis sebuah tafsir besar yang menjadi rujukan utama umat Islam nusantara. Dalam menafsirkan ayat-ayat al-Qur'an Abdul Rauf menempatkan perbedaan qira'at sebagai salah satu fokus penafsirannya. Namun, Syaikh Abdul Rauf hanya menukil tiga qira'at dari tujuh qira'at yang dianggap mutawatir dan sahih. Ketiga qira'at tersebut adalah qira 'at Imam Nafi', qira'at Imam Abu Amru, dan Qira'at imam Hafash. Penelitian ini menunjukkan bahwa meskipun perbedaan qira'at berimplikasi kepada perbedaan makna dan pemahaman, namun Syaikh Abdul Rauf hanya sekedar memberikan informasi tentang perbedaan bacaan kepada para pembaca daripada menunjukkan perbedaan makna yang dikandung oleh masing-masing perbedaan yang terjadi.
\end{abstract}

Kata Kunci: Qira'at, Turjuman al-Mustafid, Abdul Rauf Singkel, dan Tafsir. 


\section{Introduction}

It is the fact that most scholars of qira'at interpretation mastered their field. By mastering the science of qira'at interpretation, the patterns of the interpretation would be more opened. The interpretation as a result of the patterns would be no longer having single meaning but varied. The variation of meanings become an important alternative for the reader in choosing suitable atmosphere in committing the values in the alQur`an for everyday life.

Basically, the variation of readings occurred when the al-Qur'an was revealed to tribal background of the Companions of the Prophet ${ }^{1}$ in order to facilitate the community to read and to understand the al-Qur'an until the days of classical commentaries as found in the book of Tafsir by al-Tabari, Tafsir al Zamakhsyari and tafsir al Razi. ${ }^{2}$ All of the books were written in the Arabian Peninsula. In addition, it is also the manifestation of the love of Allah towards mankind. Consequently, an important message of God to man that life cannot be imposed by one color only. There is an option that can be taken in carrying out God's will in accordance with the circumstances and the human condition.

Tafsir Turjuman al-Mustafid which was written by Shaykh Abdul Rauf Singkel has become an influential book of Qur'anic exegesis and has played an active role in improving the understanding of al-Qur'an by Muslim in the Indonesian archipelago as well as building the community with high tolerance both Muslims themselves and other religious community. The emergence of high tolerance appeared through a long process.

The authors are keen to pass the research and study of the explanation of the differences

${ }^{1}$ Lilik Ummu Kultsum, Pergeseran Urgensitas Pencantuman Ragam Qira'at Dalam Kiteratur Tafsir (Jakarta: Fakultas Ushuluddin UIN Jakarta, 2013), 1.

${ }^{2}$ Muhammad Nawaf Azimi dan Muhammad Faizul Amri, Metodologi Qira'at Syaikh Muhammad Amin al Harary", Dalam Prosiding Seminar Serantau Pengajian Qira'at (SISOEQ) 2015 (Trengganu: UKM dan Institut al-Qur'an Trengganu, 2015), 42. qira'at in Tafsir Turjuman al-Mustafid written by Shaykh Abdul Rauf Singkel. It is considered important to see how the discussion qira'at alQur'an made by Sheikh Abdul Rauf, so it can serve as valuable input for the interpretation of the Koran enthusiasts today.

\section{CVs of Shaykh Abdul Rauf Singkel}

Shaikh Abdul Rauf Singkel originally named Abdul Rauf Ali al Jawi al-Fansuri al-Singkili. His Persian ancestors came to the Kingdom of Pasai at end of $13^{\text {th }}$ century. He was a great scholar of Aceh and was very famous in the spread of Islam on the island of Sumatra. Shaikh Abdul Rauf was born in 1615 but another reference said in 1593 AD. ${ }^{3}$ This Muslim Scholar was also known as Tengku Syiah Kuala. ${ }^{4}$

Abdul Rauf Singkel started his education by learning from his beloved father, Ali al-Fansuri. Then, he continued his education in the city of Fanshur, a place for the center of trade and Islamic education in Sumatra. The word Singkel was a district in Aceh called Singkil.

Aceh is an area that has contributed greatly to the development of Islam in the Indonesian archipelago. The Acehnese long been very proud of their area, especially the pride embedded with Islamic identity. They are always proud as the porch of Mecca. This is not only due to the implementation of Islamic teachings in their lives, but also because it is a very strategic region of Aceh as a center of transit of pilgrims or the prosecution of science for those who leaved for Arabia, especially Mecca and Medina. ${ }^{5}$

In 1652 Abdul Rauf abandon Aceh to continue their education in the Arabian Peninsula. ${ }^{6} \mathrm{He}$ studied to Shaykh al-Qushashi, and Sheikh

\footnotetext{
${ }^{3}$ Mukti Ali, Ensiklopedi Islam (Jakarta: Departemen Agama, 1992/1993), 26.

${ }^{4}$ WikiPedia. Com, didownload pada tanggal 17 Februari 2016 pukul 14.23 Wib.

${ }^{5}$ Peter G. Riddell, Islam and Malay-Indonesia World (London: C. Hurst and Co, 2001), 176.

${ }^{6}$ Saleh Putuhena, Historiografi Haji Indonesia (Yogyakarta: LKIS, 2007), 114.
} 
Ibrahim al-Kurani. Two great scholars in the Arabian Peninsula. Syakh Abdul Rauf returned to Aceh after his teacher Shaykh al-Qushashi died in 1661 AD. However, he still remained in contact with his other teacher, Shaykh Ibrahim al-Kurani especially for discussing religious problems that he encountered in Aceh. There came many questions about the problems he conveyed in Wujudiyah Sufi, and the relationship between Islamic Shari'ah and Taswawwuf. ${ }^{7}$

Communication he built with his teacher in Arab had a positive effect for the spread of Islam in the Indonesian archipelago. Abdul Rauf Singkel, a major supporter of intellectual and spiritual relations between scholars of Nusantara (Malay) with the Ulama in the center of Islamic civilization had made sufi-based Shari'ah spread in the archipelago at that time. ${ }^{8}$

Science and Islam developed by ShaikhAbdul Rauf Singkel attracted students from various parts of the archipelago. They came to study and explore the understanding of religious teachings of the congregation he had developed. Carrying big names who had become his disciples, among others Shaikh Burhanuddin of Ulakan Minangkabau Pariaman. Shaikh Burhanuddin developed Syatariah congregation upon his return to Ulakan. Then, Shaykh Abdul Muhyi of Karang Pamijahan West Java was also his student. And there was also Sheikh Abdul Malik bin Abdullah, best-known as Tok Pulau Manis of Trengganu, Peninsular Malaysia. ${ }^{9}$

Shaikh Abdul Rauf Singkel was a scholar as well as a very prolific writer. According to Voorhove, quoted by Liaw Yock Fang, Shaykh Abdul Rauf had written 21 books during his lifetime. ${ }^{10}$ Although there were some doubts

\footnotetext{
${ }^{7}$ Oliver Leamen (ed.), The Biographical Encyclopedia of Islamic Philosophy (London: Bloomsbury, 2015), 461.

${ }^{8}$ Rosani Hasyim (ed.), Reclaiming the Conversation Islamic Intelectual Tradition In The Malay Archipelago (Kuala Lumpur: The Other Press, 2010), 169.

${ }^{9}$ Peter G. Riddell, 178.

${ }^{10}$ Liaw Yock Fang, A History of Classical Malay Literature, (Singapura: ISEAS, 2013), 325.
}

expressed by some historians. But certainly, Azyumardi Azra cited the opinion that many works of Abdur Rauf Singkil were published by his students. Among others are: ${ }^{11}$

- Mir'at al-Fi Thullab Tasyil Mawa'iz alBadî'rifat al-Ahkam Syar'iyyah li al-Malik $a l$-Wahhab, works in the field of figh or Islamic law, which was written at the request of Sultanah Safiyatuddin.

- Tarjuman al-Mustafid, a first draft complete Tafsir al-Qur'an in Malay.

- Translation Arba'in Hadith by Imam alNawawi, written at the request Sultanah Zakiyyatuddin.

- Mawa'iz al-Badi', containing a number of important advice in coaching behavior.

- Tanbih al-Masyi, Sufism is a text that includes teaching about the dignity of seven.

- Kifayatal-Muhtajin Masyrahilaal-Muwahhidin al-Qâilin bi Wahdatil Wujud, contains a description of the concept wahdat form.

- Daqâiq al-Hurf, the teachings of Sufism and theology.

Shaikh Abdul Rauf Singkel died in 1693 AD and was buried near the mouth of the river or the Kuala Aceh. This place was also ultimately the place where his wife was buried and his disciples Daud al-Rumi and other pupils. At this time the burial site has become one of the most important places of pilgrimage which become tourist's destination in Nangro Aceh Darussalam.

\section{Tafsir Turjuman al-Mustafid}

Tafsir Turjuman al-Mustafid regarded as the first book of Tafsir al-Qur'an in the Indonesian archipelago. According to Riddell, ${ }^{12}$ the tafsir

\footnotetext{
${ }^{11}$ Azra, Azyumardi, Jaringan Ulama: Timur Tengah dan Kepulauan Nusantara Abad XVII dan XVIII, Cetakan I (Jakarta: Kencana, 1998).

${ }^{12}$ Indonesian Archipelago (Nusantara) is a term used to figurize geografical-anthropological unity of all the islands between Asian and Australian continents, ingcluding Peninsular Malaysia excluding the Philippines. For this reason, Nusantara is the equivalent of all the islands spread away in Malay Archipelago, the opular term used in the $19^{\text {th }}$ century until early of $20^{\text {th }}$
} 
was completed by Abdul Rauf in $1675 \mathrm{AD}^{13}$ made many expert's opinion provided an assessment of the book of this commentary. But in general, Riddell said that this interpretation is the combination of two important things:

1. The primary source of interpretation. According to this interpretation is the main source of interpretation Jalalain book, written by Imam Jalaluddin al-Suyuti and Jalaluddin al-Mahalli. While Tafsir al Baidhawi and Tafsir al-Khazin is a secondary source that also adorn the variation of the angle of interpretation with smaller amounts. ${ }^{14}$

2. The author of Tafsir. According to Riddell, lead author of the commentary Turjuman al-Mustafid is Abdul Rauf Singkel. Shaikh Abdul Rauf Sinkel use Jalalain as the main source of his interpretation. Meanwhile his student named David Rumi provide additional explanations and interpretations derived from Tafsir al Baidhawi, tafsir alKhazin and other sources.

Riddell opinion is certainly reject the baseless accusations of Snouck Horgronje who said that Tafsir Turjuman who has painstakingly written by al Singkili as an ordinary translation Tafseer al Baidhawi. Snouck outlook may be indicated an attempt to be little and looked weak ability Nusantara scholars in developing Islamic sciences in the archipelago. Riddell looked Snouck had erred in reaching conclusions on the interpretation Turjuman al Mustafid. ${ }^{15}$

Muhammad Yussuf and Wan Zulkifli Wan Abdullah Nasyruddin stated that the book was not a translation of Tafsir Turjuman al Mustafid by al Baidhawi and Jalalain. ${ }^{16}$ It is based on

century, It is stated mainly in the British Encyclopedia (Source: Wikipedia.com).

${ }^{13}$ Peter G Riddell, 161

${ }^{14}$ Ibid., 161

${ }^{15}$ Liaw Yock Fang, 325.

${ }^{16}$ Zulkifli Muhammad Yussuf dan Wan Nasyruddin Wan Abdullah, "Dalam Turjuman al-Mustafid, Satu Analisa Terhadap Karya Terjemahan", dalam Jurnal Pengajian Melayu 16 (2005): 160. several important references as the following:

1. The methodology for translating was very different from that of Imam al Baidhawi's work. Imam al Baidhawi laid hadiths on the fadhilah virtues or the Surahs of the Qur'an at the end of each Surat, but Shaikh Abdul Rauf put it in the beginning of the Surat.

2. Shaikh Abdul Rauf did not deeply discuss the cases related to nahwu and ' $i$ 'rab of alQur'an, except in a few places, but imam alBaidhawi conducted in-depth discussions at almost all places in his commentary.

3. The discourse on qira'at al-Qur'an in Tafsir Turjuman al Mustafid involved only three Ulamas, namely Imam Nafi', Imam Abu Amr and Imam Asim. But the interpretation of al Baidhawi's qira'at in cluded all the valid qira'at.

Here are some important evidences that the book of Tafsir Turjuman al-Mustafid did not indicate a translation of commentary of the books that ever came before. But an original work of Imam Abdul Rauf Singkel only cited al Baidhawi, al-Khazin and Jalalin as references to reinforce his own interpretation.

Ali Hasymi, cited from Azyumardi Azra, said that Tafsir Turjuman was written when al Singkili were in India. ${ }^{17}$ But for Azyumardi, it was also possible he wrote the book on the way of his traveling. The writers believed that expressing brilliant ideas related to a magnum opus was not an easy decision and could not be done at a particular time. Writing should be seriously done alone even if writing a commentary book that needs some very important references.

Tafsir Turjuman al-Mustafid is considered a first classic interpretation book in the Indonesian archipelago. It is not strange when the writer referenced to both in Indonesian and Malay. The publication of the book can be found in Malaysia, Indonesia and even in South Africa. Editions

${ }^{17}$ I.K. Khan, Islam in Modern Asia (New Delhi: MD Publications Pvt ltd. 2006), 80. 
of this commentary has also been published in Singapore, Jakarta, Penang, and Bombay, India. Some cities in the Middle East also published several editions of this commentary. For example, in Istanbul, Turkey. Mathba'ah al-Ottomans in Istanbul has published this interpretation in $1884 \mathrm{AD}$ and in 1906. In Khairo, Egypt, Sulaiman al Maraghi's publisher also published this commentary. Likewise, with al Amiriyyah Printing Press in the city of Mecca, also published the commentary of Turjuman al Mustafid. ${ }^{18}$ The last edition was printed by a publishing house in Jakarta in 1981.

The number of printings which published the book demonstrated great interest of Muslims in some parts of the world to learn about this interpretation. This may be due to the high level of curiosity of Muslims against the interpretation of the al-Qur'an in Malay language. Most of Tafsir books were written in Arabic before Shaykh Singkili's work, making it difficult for the majority of Muslims understood the meaning of al-Qur' an due to limited understanding of the Arabic language. Tafsir Turjuman al-Mustafid was written using Malay language in the Jawi script. This script used Arabic alphabet with some additional letters used to write in Malay. ${ }^{19}$

Tahlili was the method used by Abdul Rauf Singkel in interpreting verses of al-Qur'an. According to M. Quraish Shihab, tahlili method is a way of interpreting in which the commentators are trying to explain the content of the Quranic verses from a variety of aspects with regard to the sequence of verses in the al-Qur'an as contained manuscripts. Abdul Rauf Singkel indeed uses this method of interpretation..$^{20}$ It can be seen from the first page of his commentary book that begins with a discussion of the letter of al-Fatihah, followed by subsequent letters in

\footnotetext{
${ }^{18}$ Azyumardi Azra, The Origin of Islamic Reformism In Southeast Asia (Australia: Allen and Unwin, 2004), 80.

${ }^{19}$ Wikipedia.com, didownload pada tanggal 1 Maret 2016, pada pukul 15.10 wib.

${ }^{20}$ M. Quraish Shihab, Wawasan al-Qur'an (Bandung: Mizan, 2004), 86
}

accordance with the arrangement of letters from the manuscripts of al-Qur'an. In the end the explanation concluded with the interpretation of the letter al-Nas.

The interpretation of each letter was always preceded by a brief description of its background. Abdul Rauf gave explanation on the number of verses contained in the letter, Makkiyah or Madaniyyah then explained the readers on fadhilah (advantages) of reading each letter. The word fadhilah of every letter inspired Abdul Rauf based on the explanations by Salaf scholars who came before him, especially the opinion of Imam al Baidhawi. ${ }^{21}$

\section{Qira'at al-Qur'an in the Tafsir Turjuman al- Mustafid}

Imamaz-Zarkasyi defined qira 'at as differences to pronounce lafadz-lafadz (pronunciation) of al-Qur'an, either in relation to the letters or the pronunciation of letters, such as takhfif (to lighten) tastqil (make heavy use of), and many others. ${ }^{22}$ Qira'at al-Qur'an essentially provides two important indications for the Islamic Ummah in interacting with the al-Qur'an:

1. Provide convenience to Muslims in reading each sentence in the al-Qur'an. Adjusting to their ability to melafazkan each letter correctly.

2. Different qira'at can of course affect the broad and capacious meaning of the interpretation made by a commentator.

As far as the interpretation is concerned, qira'at expands the meaning of the interpretation and provides an alternative to have more capacious meaning. This is certainly a very valuable space for Muslims in applying the values of the al-Qur'an. Therefore, the tafsir

\footnotetext{
${ }^{21}$ This is exactly similar to the explanation of Surat al Fatihah. For this case, Abdul Rauf stated that Surat al-Fatihah was a Makkiyah category and it consisted of seven verses. Abdul Rauf also cited Imam al-Baidhawi who said that Surat al-Fatihah was the healing verse for any disease.

${ }^{22} \mathrm{Badr}$ ad- D in Muham bin 'Abdillah az-Zarkasyi, Al-Burhan fi'Ulum al-Qur'an, jilid I (Khairo: Dar alfikr, 1982), 395.
} 
which is categorized into mu'tabar always hold and make qira'at as an integral part of the interpretation of the al-Qur'an. This kind of tafsir is called al-Tabari.

The author of Turjuman al Mustafid also followed al-Tabari's framework in using qira 'at as one of the media in interpreting the alQur'an. There were major differences between these two frameworks. Tafsir al-Tabari opened upto various qira'at either mutawatir and mashur, even there was sometime only one of them. This is understandable because during the time of al-Tabari's tafsir, qira'at had not yet been systematically arranged as what we obtain at present. No classification of qira'at to mutawatir, mashur (famous) or syaz. While the exegesis book of Turjuman al Mustafid confined to three types of qira'at. The explanation of the three types of qira'aat had been started by Shaikh Abdul Rauf since the beginning of his writing.

When interpreting the letter of al Fatihah especially in the fourth paragraph, Shaykh Abdul Rauf provided initial explanations of qira'at. The explanation began with the word "faidah" (advantage) which was placed at the beginning. Furthermore, Shaykh Abdul Rauf plastering it with the phrase: "pada menyatakan ikhtilaf antara segala qari yang tiga pada membaca kalimat "malik" (When stated the ikhtilaf between the three phases of reading the phrase "malik"). That's why Abu Amr and Nafi were 'Ittifaq (consistent) on read the phrase "ma lik" without alif, while Hafash read it with alif. This means when it is read with alif, so God who has known and belongs to all the works until doomsday.

From the brief description of qira'at when reading the fourth paragraph of al-Fatihah, the writer was actually drawing some important points of discussion about qira'at which had been conducted by Abdul Rauf Singkel as follows:
1. Shaikh Abdul Rauf explains their deviation (difference readings) among the three priests qira'at contained in sab'ah qira'at mutawatirah.

2. Furthermore, Shaykh Abdul Rauf explained Ittifaq (suitability qira'at) when it occurs between three Ulamas of qira'at.

3. Then in the next stage, Shaykh Abdul Rauf provided an explanation on the differences lead to different interpretation of the verse in question.

Here are three important points to discuss Shaykh Abdul Rauf's explanation of qira'at's. The discussion is sometimes inconsistent with what was done at the beginning. This can be seen clearly when Shaykh Abdul Rauf sometimes delimited at mentioned Imam qira'at only, and sometimes he mentioned the narrated Imam alone.

Imam Qira'ats are the Imam as ascribed for the qira 'at's names in the al-Qur'an, for example, imam Nafi', Ibn Kathsir and others. While the Imams were those in the history became narrators of the other Imams in reading the qira'at that they were leaning against the Imams. The Imams could have actually been narrated as the qira'at's imam directly or indirectly.

The writers found in the references that the differen $\mathrm{ce}$ in the interpretation was as a descriptive o rigin of Turjuman al Mustafid which were grouped into two things:

1. Attaching the qira'at's Imam. At the beginning of the interpretation of the letter of al-Fatihah, Shaykh Abdul Rauf Singkel provided detail explanations of the seven illustrious qira'ats which can be used as a pattern in reading the al-Qur'an. He noted that the seven qira'ats were framed completely with all the seven narrators. But in the explanation followed, there was a degradation that of the seven Imams, only three were mentioned. The qira'at's Imam who relied upon readings were Imam Nafi', Imam Abu Amr and Imam Hafash. The case 
that this happened had made unbalance position of the Imam, where two imams were those of the first founder of qira'at, while the last one was the narrator. ${ }^{23}$ Shaikh Abdul Rauf Singkel did not explain why the three imams of qira'at he always mentioned rather than attaching four other mutawatir qira'ats. He always mentioned the three imams of qira'at by combining the similarity in reading which sometimes can also be found that he mentioned between Imam Nafi' and Abu Amr, or between Imam Nafi' and Imam Hafash or between Imam $\mathrm{Abu} \mathrm{Amr}$ and Imam Hafash.

The third combination can be seen in the following example:

a. Nafi 'with Abu Amr: Shaykh Abdul Rauf interpreted paragraph no. 5 of Surat Yusuf as follows:

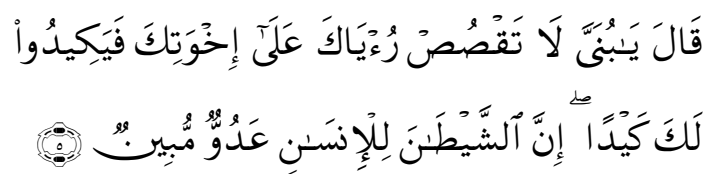

Meaning: His father said: "My son, do you tell your dream to your brothers, then they made a plot (to destroy) you. Verily, the Satan visible enemy to mankind.

When explaining the different readings in this paragraph, Shaykh Abdul Rauf wrote: the stated deviation between all reciters on the three readings on "ya bunayya and Mubin and uqtulu Yusuf'. And as for yabunayya was then he followed Imam Nafi' and Abu Amru (Ittifaq) on both especially in reading the letter kasrah "Ya" and fathah "Ya" he followed Imam Hafash's. ${ }^{24}$

\footnotetext{
${ }^{23}$ Imam Hafash adalah imam perawi dari imam Ashim. Selain Imam Hafash, ada perawi lainnya dari imam Ashim, yaitu Imam Syu'bah in Ayyash.

${ }^{24}$ Abdul Rauf Singkel, Turjuman al-Mustafid (T.tp: Dar al Fikr, 1990), 237.
}

b. Nafi 'and Hafash.

When interpreting verse 61 of Surat al-Baqarah as follows:

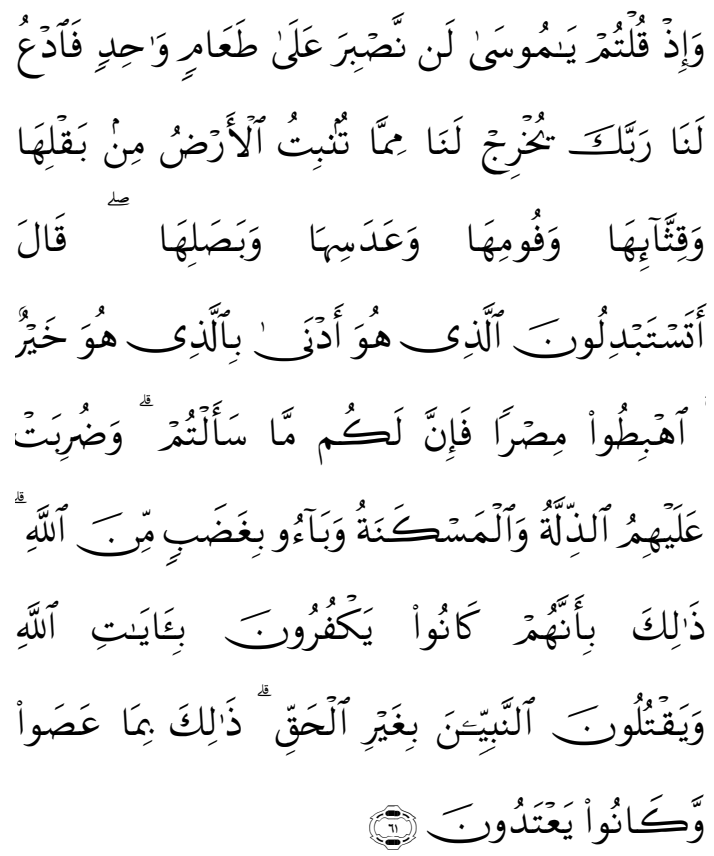

Meaning: And when you said: $O$ Musa! we cannot bear with one food, therefore pray Lord on our behalf to bring forth for us out of what the earth grows, of its herbs and its cucumbers and its garlic and its lentils and its onions. He said: Will you exchange that which is better for that which is worse? Enter a city, so you will have what you ask for. And abasement and humiliation were brought down upon them, and they became deserving of Allah's wrath; this was so because they disbelieved in the communications of Allah and killed the prophets unjustly; this was so because they disobeyed and exceeded the limits.

When it comes to an explanation of the phrase: Alaihimuzzillah Shaikh Abdul Rauf said: At stated deviation between three Qari Abu Amr read alaihumuzzillah, 
he read this phrase with "Mim" kasrah. And Nafi' and Hafash Ittifaq both on reading it with "Mim" dhummah. ${ }^{25}$

c. Abu Amr and Hafash interpreted verse 62 of Surat al Baqarah as follows:
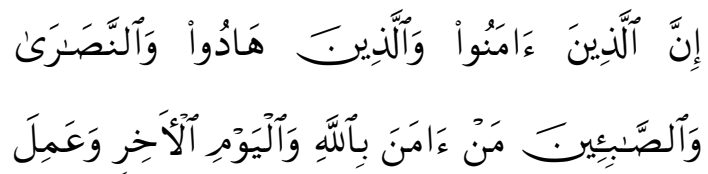

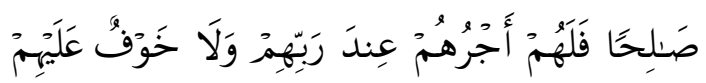

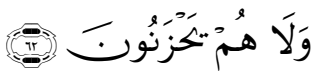

Meaning: Those who believe, and the Jews and the Christians, and those Saabien among those that believe in Allah and (believe) the Hereafter and charitable pious, so for them the reward reward is with their Lord and there is no doubt (from the entry into force of the incident were not good) to them, and they also will not grieve.

When interpreting the sentence: Asshabi'in, Shaykh Abdul Rauf put on the place of the similarities between method of reading from Imam $\mathrm{Abu} \mathrm{Amr}$ and Imam Hafash. He stated that deviation between all the three reciters when reading wasshabi'in. Then, both Abu Amr and Hafash Ittifaq on reading "hamzah" (glottal) first than " $y a$ ". While Imam Nafi' read the sentence without "hamzah."

But when explaining the verse 37 of Surat ad-Baqarah:

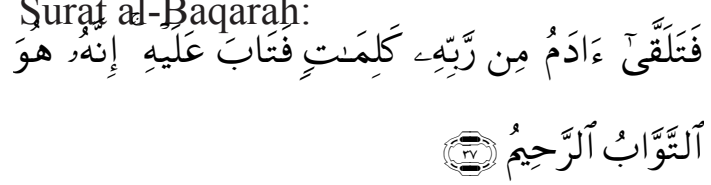

Shaikh Abdul Rauf Singkel was out of bonds of the three Imam qira'at since the beginning of his usage. $\mathrm{He}$ was entering the differences found in the reading narrated by Imam Ibn Kathir, the second qira'at's Imam. ${ }^{26}$ According to Shaikh Abdul Rauf, this verse was in line with Imam Ibn Kathir, especially when reading the word "Adam," as well as to rafa'(to pronounce) the word "kalimat". It is certainly different from the usual readings, especially in reading attributed to the Imam Hafash. Imam Hafash read (rafa') the word "adam" and then included "kasrah" when reading the word. According to Sheikh Abdul Rauf, the for form means: "there came to Adam a few sentences," namely: Rabbana zalamna anfusana until the end of the paragraph, then Adam asked God to mency upon him as stated few sentences, so accepted by God. Shaykh Abdul Rauf interpreted it "accepted by the Lord Adam" while in a few sentences gave the meaning as "accepted the repentance." And that "He who accepts repentance exceedingly gracious to them."

2. In case of mentioning Imams as narrators. Shaykh Abdul Rauf sometimes only mentioned an Imam as narrator alone. But the Imams were still within the framework of the history of qira'at narrators, among the three of them as they were always mentioned earlier. The three Imam's history was Imam Qalun, a follower of Imam Nafi', Imam ad-Duri, a narrator followed imam Abu Amr and Imam Hafash whom he never left off. Although all the three qira'at's Imam, actually there were two narrators which may be between the two, there was a difference in reading certain verses, but only Shaykh Abdul Rauf among those narrators read in the same shape as he was reading. 
It was seen when he interpreted Surat alBaqarah verse 235:

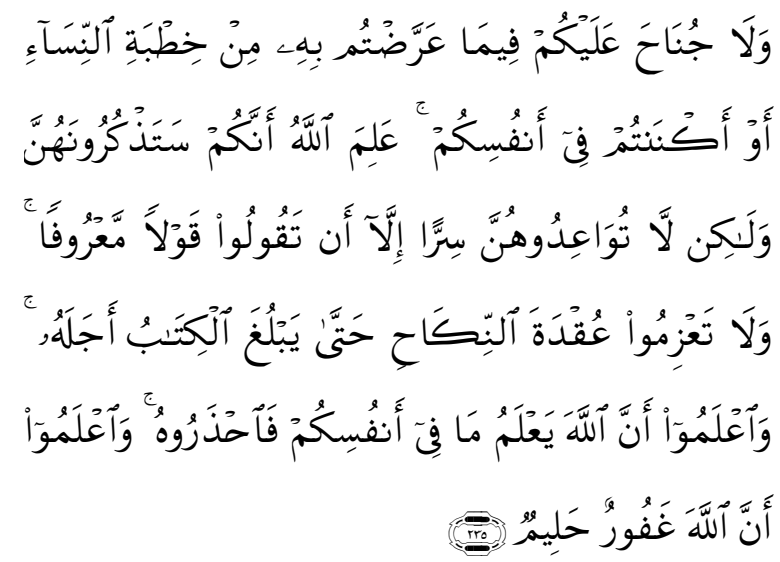

Meaning: And there is no sin for you woo the ladies with satire or stash (the desire to marry them) in your heart. Allah knows that you will mention them, in the meantime do not hold the promise to marry them in secret, except just to say (to them) words ma'ruf. And do strong initiate (committed) for promising the marriage, before it runs out the 'iddah. And know that Allah knows what is in your heart; then fear Him, and know that Allah is Oft-Forgiving, Most Forbearing.

Shaykh Abdul Rauf explained the meaning of this verse as follows: In stating any deviation between all the three reciters in reading: (أكننتم أو ألنسآ خطبة من) “min khitbati annisa aw akanantum" afored it. Both al-Qalun and ad-Duri then Ittifaq (was consistent) in reading this verse in which when the way how to read with washal should make glottal pronunciation (tahqiq) hamzah first and second should let "Ya" Maftuh be. And Hafash read both with tahqiq.

The interpretation of the Surat al-Baqarah verse 235 had shown that Shaykh Abdul Rauf was not only revealing the reading method which anchored in the qira'at's imam, also revealed his comments that the narrator's reading attributed to the Imam alone.

The difference qira'at's explanation made by Shaikh Abdul Rauf was found in almost every page of his book of commentary. In general, the difference was only a designation of the information to the readers that a few sentences and verses in the al-Qur'an can be found different ways to read and was the resources from the mentioned three qira'at's imams. Shaikh Abdul Rauf was not so much offend differences contained in the interpretation and understanding of the meaning of the verse in question. In fact, the difference in reading the al-Qur'an will be able to influence the change of meaning.

\section{Conclusion}

Shaikh Abdul Rauf Singkel was a mufassir (interpreter) of al-Qur'an who took qira'at's differences in interpretation of alQur'an. Almost every page of the book of his commentary called "Turjuman al-Mustafid" always decorated with an explanation of qira'at al-Qur'an. However, only three qira'ats were always to be a reference, he was the follower of qira'at Imam Nafi', Imam Abu Amr and Imam Hafash. No reasonable evidences why only the three qira'at's imams were referred by him in order to explin differences. Shaikh Abdul Rauf Singkel displayed mo $\mathrm{r}$ e different forms of reading only and do not use it as an alternative reading differences of interpretation to expand the reader's understanding of the meaning of the Muslims' holy book (al-Qur'an). 


\section{Bibliography}

Abdul Rauf Singkel. Turjuman al Mustafid. T.tp: Dar al Fikr, 1990.

Azyumardi Azra. Jaringan Ulama: Timur Tengah dan Kepulauan Nusantara Abad XVII dan XVIII. Cetakan I. Jakarta: Kencana, 1998.

Azyumardi Azra. The Origin of Islamic Reformism In Southeast Asia. Australia: Allen and Unwin, 2004.

Fang, Liaw Yock. A History of Classical Malay Literature. Singapura: ISEAS, 2013.

Khan, I.K. Islam In Modern Asia. New Delhi: MD Publications Pvt ltd., 2006.

Leamen, Oliver (ed.). The Biographical Encyclopedia of Islamic Philosophy. London: Bloomsbury, 2015.

Lilik Ummu Kultsum. Pergeseran Unrgensitas Pencantuman Ragam Qira'at Dalam Literatur Tafsir. Jakarta: Fakultas Ushuluddin UIN Jakarta, 2013.

M. Quraish Shihab. Wawasan al- Qur'an. Bandung: Mizan, 2004.
Muhammad Nawaf Azimi dan Muhammad Faizul Amri. "Metodologi Qira'at Syaikh Muhammad Amin al Harary". Dalam Prosiding Seminar Serantau Pengajian Qira'at (SISOEQ). Trengganu: UKM dan Institut alQur'an Trengganu, 2015.

Mukti Ali. Ensiklopedi Islam. Jakarta: Departemen Agama, 1992/1993.

Riddell, Peter G. Islam and Malay-Indonesia World. London: C. Hurst and Co, 2001.

Rosani Hasyim (ed.). Reclaiming the Conversation Islamic Intelectual Tradition In The Malay Archipelago. Kuala Lumpur: The Other Press, 2010.

Saleh Putuhena. Historiografi Haji Indonesia. Yogyakarta: Lkis, 2007.

az-Zarkasyi, Badr Ad-din Muham bin 'Abdillah. Al-Burhan fi'Ulum al-Qur'an. Jilid I. Khairo: Dar al-fikr, 1982.

Zulkifli Muhammad Yussuf dan Wan Nasyruddin Wan Abdullah. "Dalam Turjuman al Mustafid, Satu Analisa Terhadap Karya Terjemahan". Dalam Jurnal Pengajian Melayu 16 (2005). 